\title{
Wanita dalam Sistem Kewarisan Perspektif Sosiologi Hukum Islam
}

\author{
Women in the Inheritance System Perspective of Islamic Law Sociology
}

\author{
Ahmad Tahali \\ Fakultas Agama Islam Universitas Alkhairaat Palu \\ Palu, Sulawesi Tengah, Indonesia \\ tahali_ahmad@yahoo.com
}

\begin{abstract}
Abstrak
Penelitian ini bertujuan untuk mengetahui bagaimana kedudukan wanita dalam sistem kewarisan perspektif sosiologi hukum Islam. Permasalahan yang dibahas adalah mengenai bagaimana status kedudukan wanita dalam hukum waris Islam dalam prespetif sosiologi hukum waris Islam dilihat prinsip keadilan. Metode penelitian yang digunakan adalah studi kepustakaan dengan metode pendekatan yuridis normatif. Kemudian data yang diperoleh dianalisis secara komperatif. Ketentuan pembagian warisan antara laki-laki dengan wanita dalam hukum Islam telah tertuang dalam nash Al-Qur'an. Dalam hukum Islam, pembagian kewarisan bertujuan untuk mengatur masyarakat agar tercipta kemaslahatan, bukan sebaliknya diatur oleh masyarakat. Setiap ada persoalan dalam keluarga, sebaiknya diselesaikan secara kekeluargaan. Karena dengan begitu semua persoalan yang terjadi tidak begitu sulit yang kita hadapi.

Kata Kunci : Sistem Kewarisan Wanita, Sosiologi Hukum Islam
\end{abstract}

\begin{abstract}
This study aims to determine how the position of women in the inheritance system in the sociological perspective of Islamic law. The problem discussed is about how the status of women in Islamic inheritance law is in the perspective of the sociology of Islamic inheritance law in terms of the principle of justice. The research method used is literature study with a normative juridical approach. Then the data obtained were analyzed comparatively. The provisions of the distribution of inheritance between men and women in Islamic law have been stated in the text of the Al-Quran. In Islamic law, the distribution of inheritance aims to regulate society in order to create benefit, not otherwise regulated by society. Every time there is a problem in the family, it should be resolved in a friendly manner. Because then all the problems that occur are not so difficult that we face.
\end{abstract}

Keywords: Women's Inheritance System, Sociology of Islamic Law 


\section{PENDAHULUAN}

Pada zaman jahiliyah, aturan pusaka orang Arab didasarkan atas nasab dan kekerabatan. Namun terbatas kepada anak laki-laki yang sudah dapat memanggul senjata untuk membela kehormatan keluarga dan dapat memperoleh harta rampasan perang. Hal ini terus berlaku sampai permulaan Islam, sampai turunnya surat An-Nisa ${ }^{\text {ee }}$ ayat 7 yang menerangkan bahwa para lelaki memperoleh bagian dari harta peninggalan orang tua dan kerabat terdekat. Dengan turunnya ayat tersebut terhapuslah adat jahiliyah yang tidak memberikan pusaka bagi anak kecil dan perempuan (AshShiddieqy, 2010).

Dalam ajaran Islam tidak hanya mengatur masalah-masalah ibadah kepada Allah SWT saja, Islam juga mengatur hubungan manusia dengan sesamanya, yang di dalamnya termasuk masalah waris. Nabi Muhammad SAW membawa hukum waris Islam untuk mengubah hukum waris masa jahiliyah yang sangat dipengaruhi oleh unsur-unsur kesukuan yang menurut Islam tidak adil di mana hak waris hanya diberikan kepada laki-laki dewasa yang sudah mampu memanggul senjata (Suganda, 2020).

Salah satu masalah pokok yang banyak dibicarakan oleh Alquran adalah kewarisan (Parman, 1995). Hukum kewarisan Islam penerima harta warisan di dasarkan pada asas Ijbari,yaitu harta warisan pindah dengan sendirinya menurut ketentuan Allah SWT Tanpa digantungkan pada kehendak pewaris atau ahli waris (Rofiq, 2003).

Waris adalah perpindahan harta hak milik atau perpindahan pusaka, sehingga secara istilah ilmu waris adalah ilmu yang mempelajari tentang perpindahan harta pusaka peninggalan mayit kepada ahli warisnya (Hasbiyallah, 2007).

Hukum waris sangat erat kaitannya dengan ruang lingkup kehidupan manusia, bahwa setiap manusia akan mengalami peristiwa yang merupakan hukum yang lazimnya disebut dengan meninggal dunia. Apabila ada peristiwa hukum, yaitu meninggalnya seseorang sekaligus menimbulkan akibat 
hukum, yaitu bagaimana tentang pengurusan dan kelanjutan hakhak dan kewajiban seseorang yang meninggal dunia (Kasim, 2014).

Dalam pandangan Islam, kewarisan itu termasuk salah satu bagian dari fiqh atau ketentuan yang harus dipatuhi umat Islam dan dijadikan pedoman dalam menyelesaikan harta peninggalan seseorang yang telah meninggal. Allah menetapkan ketentuan tentang kewarisan ini adalah karena ia menyangkut dengan harta yang di satu sisi kecenderungan manusia kepadanya dapat menimbulkan persengketaan dan di sisi lain Allah tidak menghendaki manusia memakan harta yang bukan haknya (Syarifuddin, 2003).

Mencermati ketentuanketentuandi dalam al-Quran, dan al-Hadits, dua sumber hukum Kewarisan Islam, sepanjang mengenai kedudukan perempuan sebagai ahli waris dan perbedaan dari ahli waris laki-laki, menyangkut porsi bagian harta warisan yang diterimanya, ada persoalan yang harus dipecahkan. Kaum perempuan mempunyai kedudukan sebagai ahli waris, tetapi hak-haknya sebagai ahli waris tidak sama dengan ahli waris laki-laki (Burhan, 2017).

Hukum kewarisan Islam adalah hukum yang mengatur segala sesuatu yang berkenaan dengan peralihan hak atau kewajiban atas harta kekayaan seseorang setelah ia meninggal dunia kepada ahli warisnya. Dengan demikian, dalam hukum kewarisan ada tiga unsur pokok yang saling terkait yaitu pewaris, harta peninggalan, dan ahli waris. Kewarisan pada dasarnya merupakan bagian yang tak terpisahkan dari hukum, sedangkan hukum adalah bagian dari aspek ajaran Islam yang pokok (Anshary, 2017).

Hukum kewarisan adalah aturan-aturan tentang orang yang dikatagorikan ahli waris dengan meninggalnya seseorang, ahli waris yang berhak menerima dalam setiap kasus, hak setiap ahli waris, teknik pembagian, dan komposisi hartawarisan (Hajar, 2008).

Hukum kewarisan Islam merupakan suatu peraturan hukum yang mengatur bagaimana tata cara membagi hak dan kewajiban seorang yang telah 
meninggal dunia kepada ahli waris yang masih hidup.

Pada mula awal perkembangan Islam, nabi Muhammad SAW merupakan sosok yang tetap untuk menyelesaikan persoalan tentang hukum kewarisan. Sebab, nabi Muhammad SAW dapat menafsirkan dan menjelaskan tentang hukum kewarisan berdasarkan firman yang turun pada beliau. Kemudian nabi Muhammad SAW dapat pula berwenang membuat hukum kewarisan di luar dari firman Allah SWT.

Sebagai pelanjut risalah yang telah dicontohkan oleh Nabi Muhammad SAW, maka sahabatlah yang bertanggungjawab serta menafsirkan hukum yang terdapat dalam Alquran. Hal ini tentu saja logis karena populasi umat Islam pada saat itu bertambah kuat. Dengan permasalahan hukum kewarisan semakin kompleks, maka perlunya para sahabat untuk menafsirkan tentang harta setelah pewaris wafat.

Khalifah Abu Bakar pernah mengambil sebuah keputuskan bahwa semua harta peninggalan diwarisi oleh nenek dari ibu meskipun ia bersama nenek dari ayah. Khalifah Umar bin Khattab, juga hanya memberikan saham kepada ahli waris: yaitu suami, ibu, dan dua saudara laki-laki seibu tanpa harus memberikan saham kepada saudara laki-laki sekandung. Khalifah Umar berpendapat bahwa ketiga jenis ahli waris itu mendapat saham yang ditentukan dalam Alquran. Pada Umar pernah terjadi sebuah kasus saudara sekandung tersebut mengajukan sebuah keberatan tentang pembagian kewarisan bahwa paling tidak menurutnya ahli waris mempunyai ibu yang sama dari pewaris. Dengan demikian, maka terjadilah sebuah hubungan kekeluargaan yang sama dengan saudara seibu. Pemikiran tersebut diterima oleh Umar sebagai saudara sekandung dan dapat berbagi rata dengan saudara seibu. Sikap kompromi inilah yang dikenal dalam sejarah Islam khususnya hukum kewarisan sebagai kasus himariyah. Khalifah Ali bin Abi Thalib, pernah mengurangi nilai saham para ahli waris secara proposional karena saham-saham yang telah diterapkan dalam 
Alquran ternyata melebihi kesatuan. Dalam hal ini, Ali memberikan saham kepada isteri kurang dari nilai saham yang seharusnya. Dengan demikian, ahli waris: dua anak perempuan, ayah, dan ibu secara otomatis berkurang nilainya secara proposional pula (Parman, 1995).

Dalam hukum kewarisan Islam tentunya sudah diatur dengan jelas. Namun pada kenyataannya di tengah-tengah masyarakat masih saja belum tersosialisasi dengan baik. Hal ini disebabkan oleh penduduk Indonesia memiliki berbagai macam ragam budaya. Sehingga bergam inilah yang menyebabkan masyarakat tidak memiliki satu bentuk hukum.

\section{METODE PENELITIAN}

Pendekatan yang penulis gunakan dalam penulisan ini ialah melalui pendekatan teologis dan sosiologis yakni segala hal yang menyangkut masalah kewarisan dianalisa berdasarkan konsep dan teori hukum Islam.

Dalam pengumpulaan data sebagai bahan penelitian, penulis menggunakan riset (Library Reseach) yakni dengan membaca buku-buku serta bahan bacaan lainnya yang relevan dengan masalah yang dibahas. Kemudian mengutip atau mengihtisarkan suatu uraian tertentu atau mengulas dan selanjutnya mengambil kesimpulan.

Dalam hal mengelolahan data, penulis menggunakan metode secara kualitatif. Dengan kata lain, tulisan ini tidak mengumpulkan data yang harus diolah secara kuantitatif.

Analisa yang digunakan adalah analisis komparatif yaitu suatu usaha untuk mencari pemecahan masalah melalui analisis tentang hubungan sebab akibat, yaitu meneliti faktorfaktor tertentu yang berhubungan dengan situasi dan fenomena yang diselidiki dan membandingkan dengan faktorfaktor lain. Adapun dalam penelitian ini penulis menggunakan alur berpikir induktif. Alur berpikir induktif merupakan metode berpikir yang bertitik tolak dari data-data khusus yang ada hubungannya dengan penelitian, kemudian diambil kesimpulan yang bersifat umum. 


\section{III.HASIL}

\section{PEMBAHASAN}

\section{A. Pengertian Kewarisan}

Dalam bahasa Arab al-Irts adalah bentuk mashdar dari kata waritsa, yaritsu, irtsan. Bentuk mashdar-nya bukan saja kata irtsan, melainkan termasuk juga kata wirtsan, turtsan, dan wiratsatan. Waritsa, yang berakar kata dari huruf-huruf waw, ra, dan tsa yang mempunyai perpindahan harta milik, atau berpindahan sebuah pusaka (Parman, 1995). Al-Irts artinya harta warisan yang siap dibagikan oleh ahli waris sesudah diambil untuk kepentingan pemeliharaan jenazah (tajhiz al-janazah), pelunasan hutang serta pelaksanaan wasiat (Rofiq, 1998).

Irts terulang 22 kali dalam Al-Quran dalam berbagai bentuknya. Dalam tulisan ini dibatasi pada beberapa ayat yang teks selengkapnya sebagai berikut:

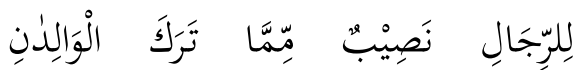

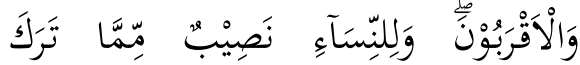

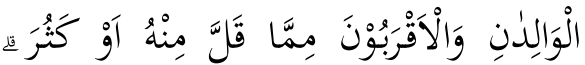

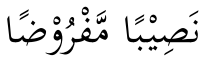

"Bagi orang laki-laki ada hak bagian dari harta peninggalan ibu-bapa dan kerabatnya, dan bagi orang wanita ada hak bagian (pula) dari harta peninggalan ibu-bapa dan kerabatnya, baik sedikit atau banyak menurut bahagian yang telah ditetapkan". (QS. An-Nisa [4]: 7)

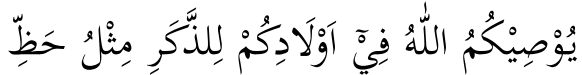

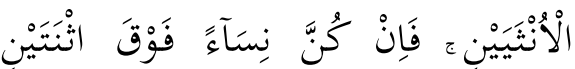

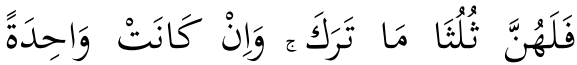

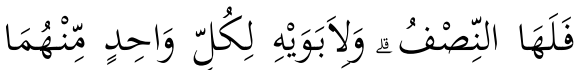

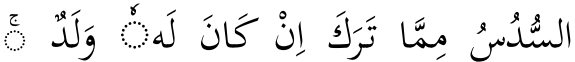

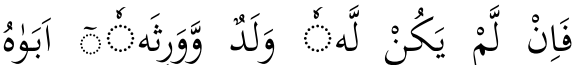

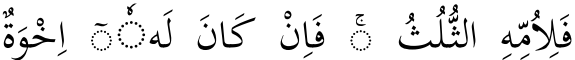

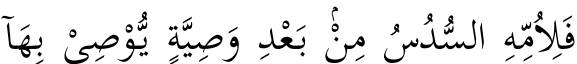

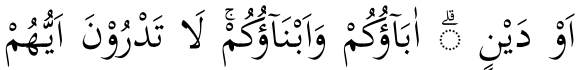

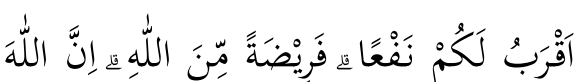
كَانَ عَلِيمًا حَكِكْمَا "Allah mensyari'atkan bagimu tentang (pembagian pusaka untuk) anak-anakmu. Yaitu : bahagian seorang anak lelaki sama dengan bagahian dua 
orang anak perempuan, dan jika anak itu semuanya perempuan lebih dari dua, Maka bagi mereka dua pertiga dari harta yang ditinggalkan; jika anak perempuan itu seorang saja, Maka ia memperoleh separo harta. dan untuk dua orang ibubapa, bagi masing-masingnya seperenam dari harta yang ditinggalkan, jika yang meninggal itu mempunyai anak; jika orang yang meninggal tidak mempunyai anak dan ia diwarisi oleh ibu-bapanya (saja), Maka ibunya mendapat sepertiga; jika yang meninggal itu mempunyai beberapa saudara, Maka ibunya mendapat seperenam. (Pembagian-pembagian tersebut di atas) sesudah dipenuhi wasiat yang ia buat atau (dan) sesudah dibayar hutangnya. (Tentang) orang tuamu dan anak-anakmu, kamu tidak mengetahui siapa di antara mereka yang lebih dekat (banyak) manfaatnya bagimu. ini adalah ketetapan dari Allah. Sesungguhnya Allah Maha mengetahui lagi Maha Bijaksana". (QS. An-Nisa [4]: 11)

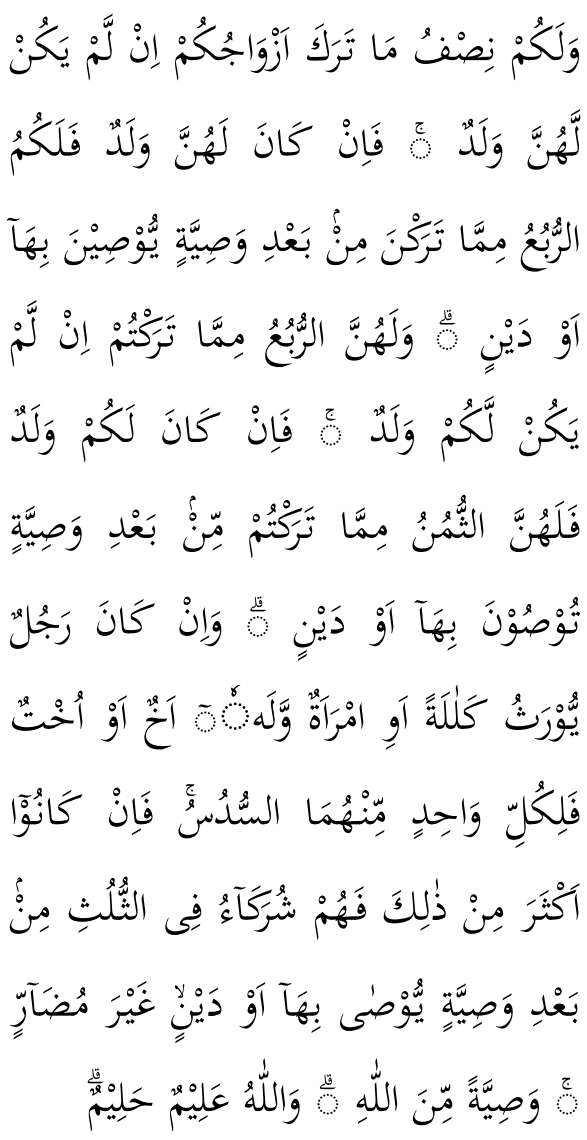

"Dan bagimu (suami-suami) seperdua dari harta yang ditinggalkan oleh isteri-isterimu, jika mereka tidak mempunyai anak. jika isteri-isterimu itu mempunyai anak, Maka kamu mendapat seperempat dari harta yang ditinggalkannya sesudah dipenuhi wasiat yang mereka buat atau (dan) seduah dibayar hutangnya. Para isteri memperoleh seperempat harta yang kamu tinggalkan jika kamu 
tidak mempunyai anak. jika kamu mempunyai anak, Maka Para isteri memperoleh seperdelapan dari harta yang kamu tinggalkan sesudah dipenuhi wasiat yang kamu buat atau (dan) sesudah dibayar hutang-hutangmu. Jika seseorang meninggal, baik lakilaki maupun perempuan yang tidak meninggalkan ayah dan tidak meninggalkan anak, tetapi mempunyai seorang saudara lakilaki (seibu saja) atau seorang saudara perempuan (seibu saja), Maka bagi masing-masing dari kedua jenis saudara itu seperenam harta. Tetapi jika saudara-saudara seibu itu lebih dari seorang, Maka mereka bersekutu dalam yang sepertiga itu, sesudah dipenuhi wasiat yang dibuat olehnya atau sesudah dibayar hutangnya dengan tidak memberi mudharat (kepada ahli waris). (Allah menetapkan yang demikian itu sebagai) syari'at yang benar-benar dari Allah, dan Allah Maha mengetahui lagi Maha Penyantun”. (QS. An-Nisa : 12)
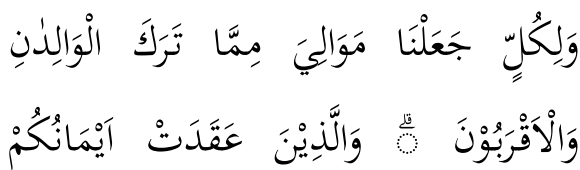
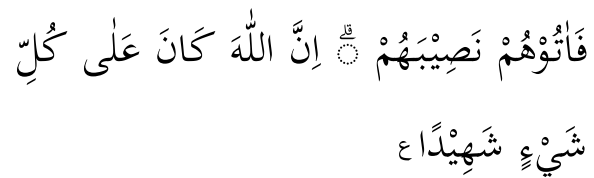

"Bagi tiap-tiap harta peninggalan dari harta yang ditinggalkan ibu bapak dan karib kerabat, Kami jadikan pewarispewarisnya. Dan (jika ada) orang-orang yang kamu telah bersumpah setia dengan mereka, Maka berilah kepada mereka bahagiannya. Sesungguhnya Allah menyaksikan segala sesuatu”. (QS. An-Nisa [4]: 33)

Ayat tersebut berbicara dalam konteks peralihan harta pusaka seseorang kepada orang lain. Al-Raghib al-Ashfahaniy menjelaskan secara khusus bahwa pengalihan harta pusaka yang dikendaki oleh ayat 11 dan 12 di atas terdiri dari dua kemungkinan. Pertama, pewaris harus mempunyai keturunan. Kedua, pewaris tidak mempunyai keturunan. Konsekuensi kedua hal tersebut adalah bahwa peralihan harta pusaka tetap terlaksanakan, meskipun pewaris tidak mempunyai keturunan.

Faraid menurut bahasa artinya bagian atau qadar. Menurut istilah syara' berate 
bagian yang ditentukan dari harta benda yang akan dipusakai (Masud dan Abidin, 2000).

Ilmu faraid ini dikenal juga dengan nama ilmu untuk memahami pembagian harta pusaka, ilmu yang dipergunakan untuk mengetahui ketentuan tiaptiap orang yang mempunyai hak pada tirkah (harta benda yang ditinggalkan si pewaris). Allah SWT. berfirman:

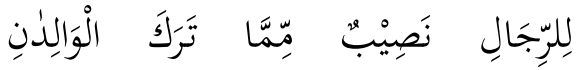

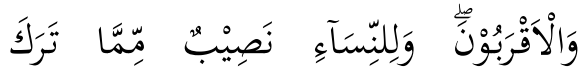

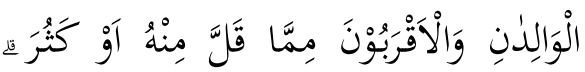
نَصِيْبًا مََْْرُوْوضًا "Bagi laki-laki dan hak bagian dari harta peninggalan ibu bapak dan kerabat-kerabatnya dan bagi perempuan ada pula hak bagian dari harta peninggalan ibu bapak dan kerabatnya, baik sedikit atau banyak, menurut bagian yang telah ditentukan." (Q.S. An-Nisa: 7)

Dalam hadits Rasulullah SAW. disebutkan:

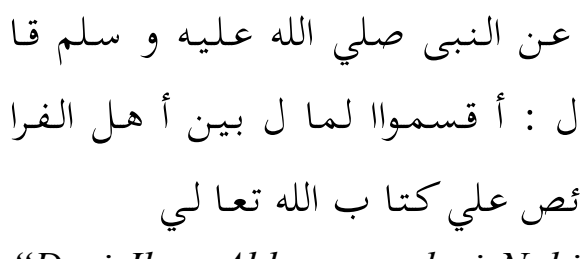

"Dari Ibnu Abbas r.a. dari Nabi SAW., beliau bersabda, "bagibagilah harta benda di antara ahli faraid, menurut kitab Allah." (H.R. Muslim dan Abu Dawud)

Faraid adalah hukum kewarisan yang diikuti oleh umat Islam dalam usaha mereka menyelesaikan pembagian harta peninggalan keluarga yang meninggal dunia (Syarifuddin, 2004). Negara yang berpenduduk mayoritas beragama Islam hukum faraid telah menjadi hukum fositif. Di Indonesia hanya berlaku kepada yang bergama Islam, tidak berlaku secara nasional.

Kewarisan ialah hukum yang mengatur cara-cara peralihan hak dari seseorang yang telah meninggal dunia kepada orang yang masih hidup. Dan ketentuan-ketentuan tersebut berdasarkan firman Allah yang terdapat dalam Al-Qur'an, serta di oleh Nabi Muhammad SAW (Djakfar dan Yahya, 1995). 
Tirkah yaitu harta peninggalan orang meninggal setelah diambil biaya-biaya perawatan, melunasi utang-utang, dan melaksanakan wasiat (Haffas, 2002). Tarikah atau tirkah, dalam bahasa searti dengan mirats atau harta yang ditinggalkan. Kebenarnya, harta yang ditinggalkan oleh seseorang pemilik harta untuk ahli warisnya, dinamakan tarikah orang meninggal (tarikatul maiyiti) (Shiddieqy, 2001).

Al-Tirkah dalam bahasa Arab adalah bentuk mashdar dan kata tunggal taraka, yang berakar kata dari huruf-huruf ta, ra, $k a$. Dan tercatat 28 kali dalam alquran dalam berbagai konteks kata (Parman, 1995).

Jumhur ulama berpendapat, tarikah itu adalah yang ditinggalkan oleh seseorang sesudah ia meninggal, baik itu harta, maupun merupakan hak yang bersifat harta atau hak yang lebih kuat unsur harta terhadap hak perorangan, tanpa melihat siapa yang lebih berhak menerimahnya (Shiddieqy, 2001).

Berdasarkan pendapat ini, timbullah suatu kaidah yaitu:

$$
\text { لا تر كة إ لاّ بعد د ين }
$$

"Tak ada tarikah, melainkan sesudah hutang dilunasi."

Sebenarnya perbedaanperbedaan definisi ini tidaklah menumbuhkan sesuatu perbedaan dalam segi amaliah. Karenanya kita anggap perbedaan itu hanyalah perbedaan lafdhi atau redaksional.

Makna harta peninggalan, tercantum pada surah An-nisa ayat: $7,11,12,33$, dan 176 .

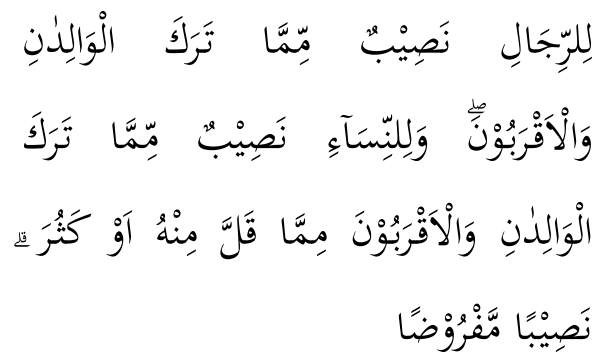

"Bagi orang laki-laki ada hak bagian dari harta peninggalan ibu-bapa dan kerabatnya, dan bagi orang wanita ada hak bagian (pula) dari harta peninggalan ibu-bapa dan kerabatnya, baik sedikit atau banyak menurut bahagian yang telah ditetapkan." (QS. An-Nisa [4]: 7)

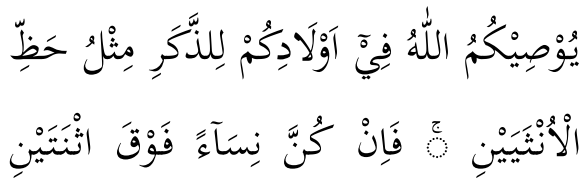




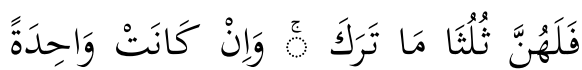

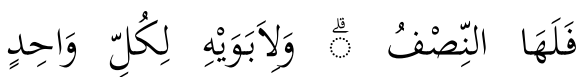

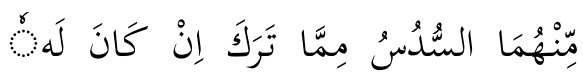

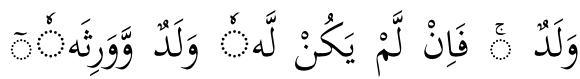

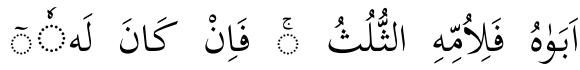

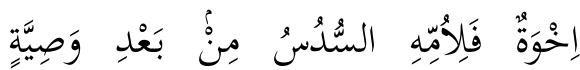

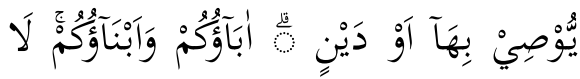

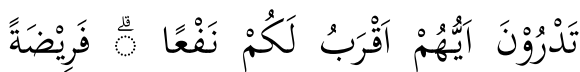

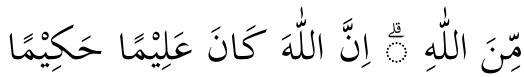
"Allah mensyari'atkan bagimu tentang (pembagian pusaka untuk) anak-anakmu. Yaitu : bahagian seorang anak lelaki sama dengan bagahian dua orang anak perempuan; dan jika anak itu semuanya perempuan lebih dari dua, Maka bagi mereka dua pertiga dari harta yang ditinggalkan; jika anak perempuan itu seorang saja, Maka ia memperoleh separo harta. dan untuk dua orang ibubapa, bagi masing-masingnya seperenam dari harta yang ditinggalkan, jika yang meninggal itu mempunyai anak; jika orang yang meninggal tidak mempunyai anak dan ia diwarisi oleh ibu-bapanya (saja), Maka ibunya mendapat sepertiga; jika yang meninggal itu mempunyai beberapa saudara, Maka ibunya mendapat seperenam. (Pembagian-pembagian tersebut di atas) sesudah dipenuhi wasiat yang ia buat atau (dan) sesudah dibayar hutangnya. (Tentang) orang tuamu dan anak-anakmu, kamu tidak mengetahui siapa di antara mereka yang lebih dekat (banyak) manfaatnya bagimu. ini adalah ketetapan dari Allah. Sesungguhnya Allah Maha mengetahui lagi Maha Bijaksana." (QS. An-Nisa [4]: 11)

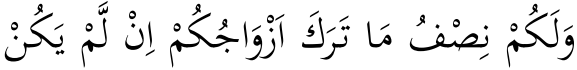

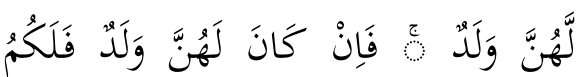

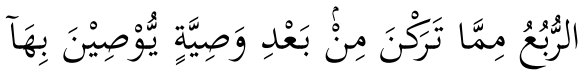

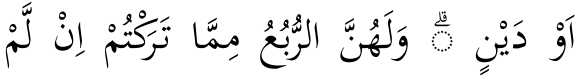

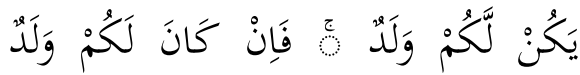

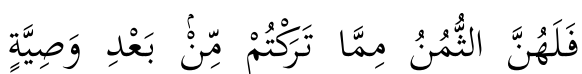

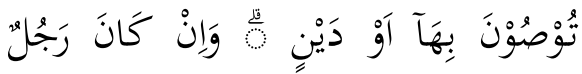

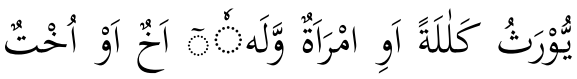




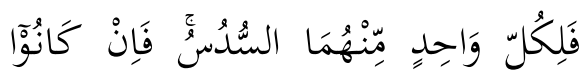

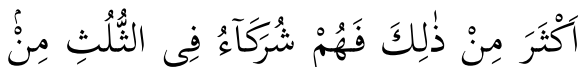

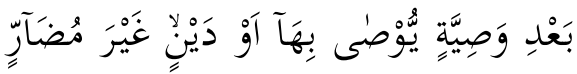

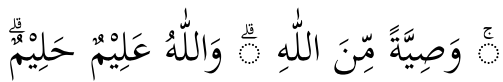

"Dan bagimu (suami-suami) seperdua dari harta yang ditinggalkan oleh isteri-isterimu, jika mereka tidak mempunyai anak. Jika isteri-isterimu itu mempunyai anak, maka kamu mendapat seperempat dari harta yang ditinggalkannya sesudah dipenuhi wasiat yang mereka buat atau (dan) seduah dibayar hutangnya. Para isteri memperoleh seperempat harta yang kamu tinggalkan jika kamu tidak mempunyai anak. jika kamu mempunyai anak, Maka Para isteri memperoleh seperdelapan dari harta yang kamu tinggalkan sesudah dipenuhi wasiat yang kamu buat atau (dan) sesudah dibayar hutang-hutangmu. Jika seseorang meninggal, baik lakilaki maupun perempuan yang tidak meninggalkan ayah dan tidak meninggalkan anak, tetapi mempunyai seorang saudara lakilaki (seibu saja) atau seorang saudara perempuan (seibu saja),
Maka bagi masing-masing dari kedua jenis saudara itu seperenam harta. Tetapi jika saudara-saudara seibu itu lebih dari seorang, Maka mereka bersekutu dalam yang sepertiga itu, sesudah dipenuhi wasiat yang dibuat olehnya atau sesudah dibayar hutangnya dengan tidak memberi mudharat (kepada ahli waris). (Allah menetapkan yang demikian itu sebagai) syari'at yang benar-benar dari Allah, dan Allah Maha mengetahui lagi Maha Penyantun." (QS. An-Nisa [4]: 12)

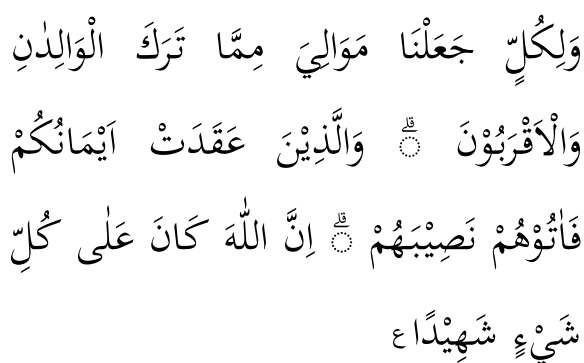

"Bagi tiap-tiap harta peninggalan dari harta yang ditinggalkan ibu bapak dan karib kerabat, kami jadikan pewarispewarisnya. Dan (jika ada) orang-orang yang kamu telah bersumpah setia dengan mereka, Maka berilah kepada mereka bahagiannya. Sesungguhnya Allah menyaksikan segala sesuatu." (QS. An-Nisa [4]: 33) 


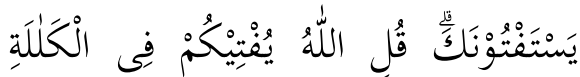

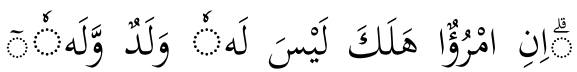

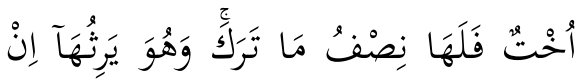

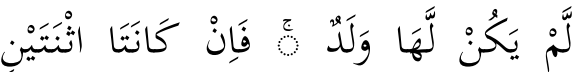

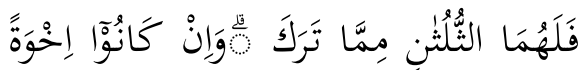

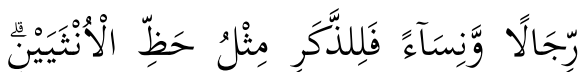

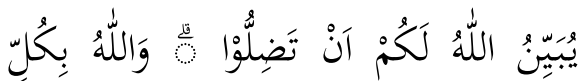

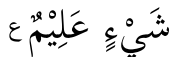
"Mereka meminta fatwa kepadamu (tentang kalalah). Katakanlah: "Allah memberi fatwa kepadamu tentang kalalah (yaitu): jika seorang meninggal dunia, dan ia tidak mempunyai anak dan mempunyai saudara perempuan, Maka bagi saudaranya yang perempuan itu seperdua dari harta yang ditinggalkannya, dan saudaranya yang laki-laki mempusakai (seluruh harta saudara perempuan), jika ia tidak mempunyai anak; tetapi jika saudara perempuan itu dua orang, Maka bagi keduanya dua pertiga dari harta yang ditinggalkan oleh yang meninggal. dan jika mereka (ahli waris itu terdiri dari) saudarasaudara laki dan perempuan, Maka bahagian seorang saudara laki-laki sebanyak bahagian dua orang saudara perempuan. Allah menerangkan (hukum ini) kepadamu, supaya kamu tidak sesat. dan Allah Maha mengetahui segala sesuatu." (QS. An-Nisa : 176)

Keseluruhan kata taraka yang terdapat dalam surah AnNisa, ayat: 4, 7, 11, 12, 33, dan 176 adalah bentuk tunggal madhi, yang pada mulanya bermakna pengalihan kekuasaan Tuhan kepada umat manusia. Kemudian kata tirkah seringkali diartikan sebagai harta peninggalan yang dipersiapkan oleh pewaris kepada ahli warisnya. Karena itu kata taraka yang berbentuk madhi mengandung pula arti bahwa Tuhan telah mempersiapkan harta untuk manusia, tinggal bagaimana manusia mengelolah harta untuk persiapan bagi ahli warisnya.

\section{B. Dasar Hukum Kewarisan}

1. Al-Qur'an

Faraidh telah diatur secara jelas di dalam Al-Qur'an, yaitu di dalam surah An-Nisa ayat 7, 11, 12, 176, dan surat-surat 
lainnya. Namun hal ini, penulis hanya menguraikan ayat 7 dan 11.

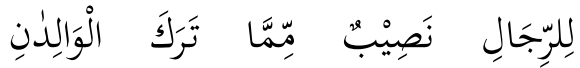

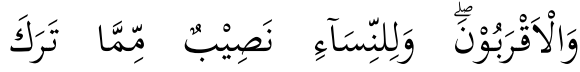

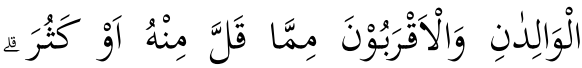

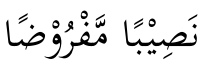

"Bagi orang laki-laki ada hak bagian dari harta peninggalan ibu-bapa dan kerabatnya, dan bagi orang wanita ada hak bagian (pula) dari harta peninggalan ibu-bapa dan kerabatnya, baik sedikit atau banyak menurut bahagian yang telah ditetapkan."

Ketentuan dalam ayat diatas merupakan merupakan landasan utama yang menunjukkan, bahwa dalam Islam baik laki-laki maupun perempuan sama-sama mempunyai hak waris, dan sekaligus merupakan pengakuan Islam, bahwa perempuan merupakan subjek hukum yang mempunyai hak dan kewajiban. Tidak demikian halnya pada masa jahiliyah, dimana wanita dipandang sebagai objek bagaikan benda biasa yang dapat diwariskan.

Sebagai pertanda yang lebih nyata, bahwa Islam mengakui wanita sebagai subjek hukum, dalam keadaan tertentu mempunyai hak waris, sedikit ataupun banyak yang telah dijelaskan dalam beberapa ayat al-Qur'an. Diantaranya terdapat dalam surah An-Nisa' ayat 11:

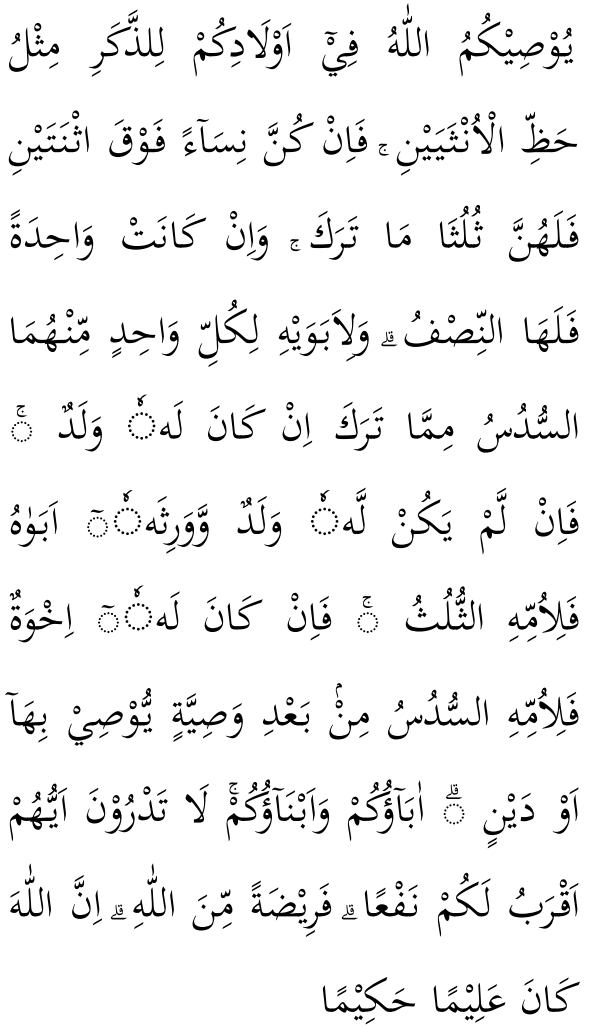

"Allah mensyari'atkan bagimu tentang (pembagian pusaka untuk) anak-anakmu. Yaitu : bahagian seorang anak lelaki 
sama dengan bagahian dua orang anak perempuan; dan jika anak itu semuanya perempuan lebih dari dua, Maka bagi mereka dua pertiga dari harta yang ditinggalkan; jika anak perempuan itu seorang saja, Maka ia memperoleh separo harta. dan untuk dua orang ibubapa, bagi masing-masingnya seperenam dari harta yang ditinggalkan, jika yang meninggal itu mempunyai anak; jika orang yang meninggal tidak mempunyai anak dan ia diwarisi oleh ibu-bapanya (saja), Maka ibunya mendapat sepertiga; jika yang meninggal itu mempunyai beberapa saudara, Maka ibunya mendapat seperenam. (Pembagian-pembagian tersebut di atas) sesudah dipenuhi wasiat yang ia buat atau (dan) sesudah dibayar hutangnya. (Tentang) orang tuamu dan anak-anakmu, kamu tidak mengetahui siapa di antara mereka yang lebih dekat (banyak) manfaatnya bagimu. ini adalah ketetapan dari Allah. Sesungguhnya Allah Maha mengetahui lagi Maha Bijaksana."

Ayat di atas menjelaskan bahwa,bahagian seorang anak lelaki sama dengan bahagian dua orang anak perempuan'. Maksudnya ketika ada anak lakilaki dan anak wanita. Tapi jika yang ada hanya anak lakilaki,maka dia mendapatkan semua warisan, jika yang ada hanya anak perempuan, maka dia mendapatkan separohnya. Jika ada dua anak perempuan maka mereka mendapat dua pertiga bagian (Khan, 2001).

2. Hadits

Diriwayatkan dari Usamah ibn Zaid r.a, bahwa beliau berkata

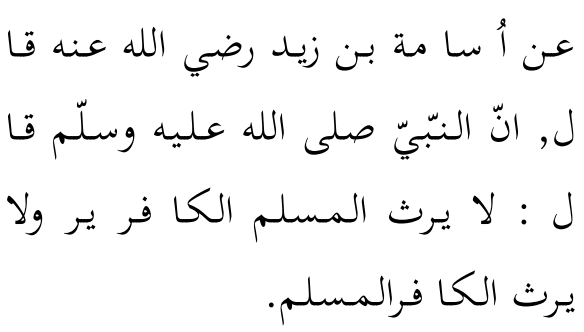

"Sesungguhnya Nabi SAW., telah bersabda: orang muslim tidak mewarisi orang kafir, dan orang kafir tidak mewarisi orang muslim." (HR. Bukhari dan Muslim)

Diriwayatkan dari Abdullah ibn Amr r.a, bahwa beliau berkata: 
عن عبد الله بن عمـر رضي الله عنه قا ل, قا ل رسول الله صلى الله عليه

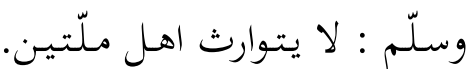
"Rasulullah SAW., bersabda:Orang yang berlainan agama tidak mawaris mewarisi." (HR. Ahmad, Abu Daud, An Nisa'i dan Ibnu Majah)

Diriwayatkan dari Amr ibn Syu'aib r.a, bahwa beliau berkata: عن عمروبن شعيب عن ابيه عن جـدّ هـ رضي الله عنهم قا ل, قان ل رسو ل الله صلى الله عليه وسلم : المبل ليس لقا تل مـ الميراث شئ. "Rasulullah SAW., bersabda: Si pembunuh tidak mendapat pusaka dari yang dibunuhnya." (HR. An Nasa'i dan Ad Daraquthni)

Diriwayatkan dari Ibnu Abbas r.a bahwa beliau berkata:

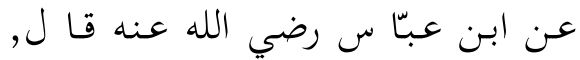
قا ل رسول الله صلى الله عليه وسلم

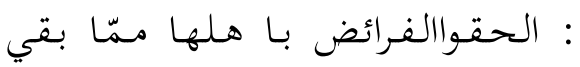
فهو لاو لى رجل ذكر.

"Rasulullah SAW., bersabda : Berikanlah harta pusaka pada pemiliknya (orang yang menerima fardlu). Sisa dari hartanya, diberikan kepada orang yang lelaki yang paling dekat kepada orang yang meninggal." (HR. Bukhari dan Muslim)

Diriwayatkan dari Al Miqdam ibn Ma'dikariba r.a, bahwa beliau berkata :

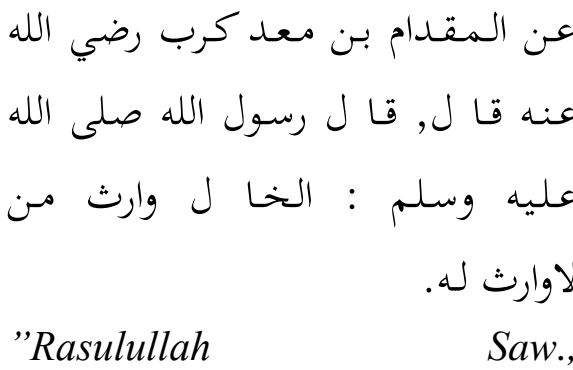
bersabda:Saudara ibu menjadi waris bagi orang yang tidak ada warisnya." (HR. Ahmad, Abu Daud, An Nisa'i dan Ibnu Majah)

Diriwayatkan dari Ibnu Umamah ibn Sahal r.a, bahwa beliau berkata :

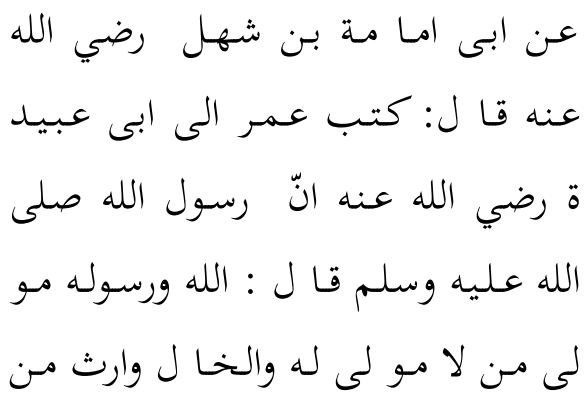
لا لارث له وارث.

"Umar menulis surat kepada abu Ubaidah menerangkan bahwa Rasulullah SAW., bersabda: 
Allah dan Rasul-Nya wali bagi orang tak ada walinya. Saudara ibu adalah waris bagi orang yang tak ada warisnya." (HR. Ahmad, An Nasa'i, At Turmudzi)

Diriwayatkan dari Umar ibn Khaththab r.a, bahwa beliau berkata:

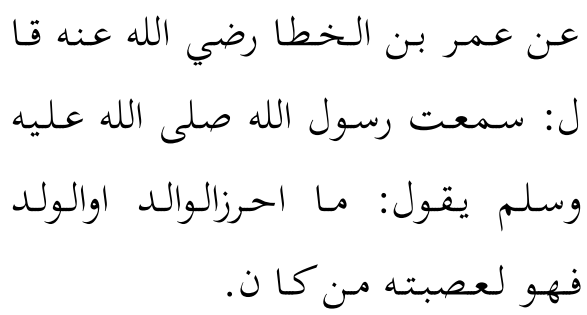

"Saya mendengar Rasulullah SAW., bersabda: apa yang diperoleh oleh si ayah atau si anak maka yang demikian itu untuk ashabahnya siapa saja dia." (HR. Abu Daud, An Nisa'i dan Ibnu Majah)

Diriwayatkan dari Ibnu Mas'ud r.a, bahwa beliau berkata: عن ابن مسعود رضي الله عنه قا ل: فى بيت ابن واخت قضى النبّيّ

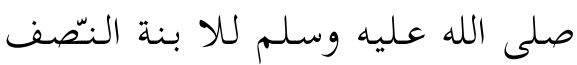

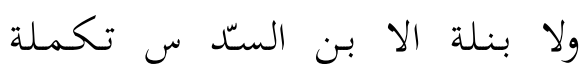

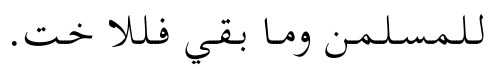
"Tentang seorang anak perempuan dan saudara anak perempuan dari anak lelaki dan saudara perempuan. Nabi SAW., telah menetapkan untuk anak perempuan dan untuk anak perempuan dari anak lelaki seperenam untuk mencukupi dua pertiga, sisanya untuk anak perempuan." (HR. Bukhari)

Diriwayatkan dari Imran ibn Husain r.a, bahwa beliau berkata : عن عمران بن حصين رضي الله عنه قا ل: جـاء رجل الى النبّيّ صلى الله رصني

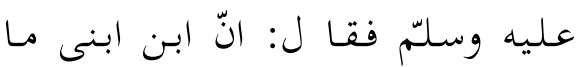
ت فما لى من مرثه ؟ فقا ل لك لك لك

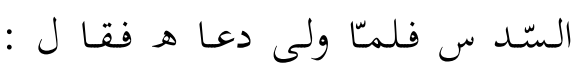
لك سـد س اخر فلما ولّى دعا هـ فقـا ل انّ السيّد س الا خر طعمـة. "Seorang lelaki datang kepada Nabi SAW., dan berkata : sesungguhnya anak lelaki dari anak lelaki itu telah meninggal, maka apa yang aku peroleh dari harta peninggalannya? Maka Nabi SAW., menjawab: Engkau memperoleh seperenam, tatkala orang itu pergi Nabi SAW. memanggilnya kembali dan Nabi SAW. berkata: Engkau memperoleh seperenam lagi. Setelah orang itu pergi Nabi SAW. memanggilnya lagi dan 
mengatakan bahwa seperenam yang kedua adalah suatu ahdiah bagimu." (HR. Ahmad, Abu Daud dan An Nasa'i, At Turmudzi dan Ibnu Majah)

Diriwayatkan dari Ibnu Buraidah dari ayahnya (Buraidah) r.a, bahwa beliau berkata:

عن ابى بر يـدة عن ابيه رضي الله عنهما قا ل: انّ النّبيّ صلى الله عليه

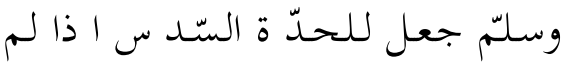<smiles>[AlH][As]C=C[As]</smiles>

"Sesungguhnya Nabi SAW., telah menetapkan seperenam untuk nenek bila tidak ada ibu." (HR. Abu Daud dan An Nasa'i)

Diriwayatkan dari Abu Hurairah r.a, bahwa beliau berkata:

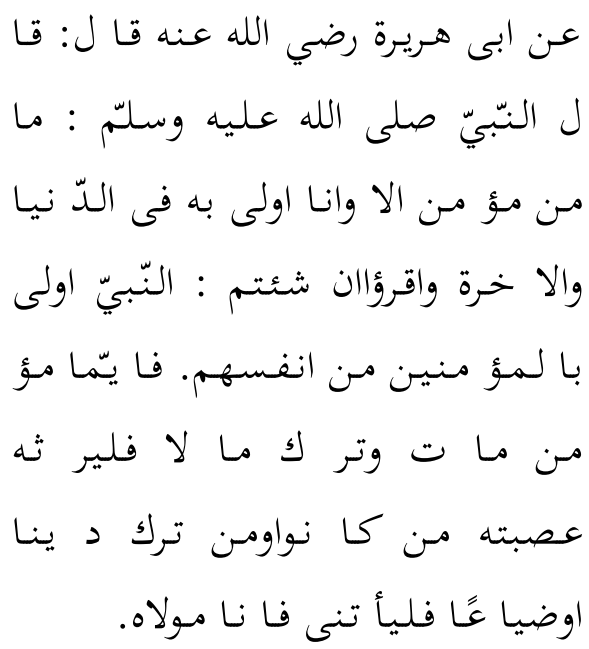

"Nabi SAW., bersabda: tidak ada seorang mukmin pun melainkan aku yang lebih aula terhadapnya di dunia dan di akhirat. Bacalah kalau kami maksud, firman Allah, Nabi SAW. lebih aula terhadap orang mukmin dari mereka. Maka siapa saja orang mukmin yang meninggal dengan meninggalkan harta, maka harta-hartanya diwarisi oleh asabahnya, siapa saja mereka itu. Dalam orang yang meninggal dengan meninggalkan hutang atau anakanak kecil, maka hendaklah dia datang kepadaku akulah walinya." (HR. Bukhari dan Muslim)

\section{Sistem Kewarisan Islam}

Hukum Islam sudah mengatur sistem kewarisan dengan cara terbaik serta akurat, dan adil. Oleh karena itu, hukum Islam mengakui adanya kepemilikan harta benda seseorang yang didapatkan dengan cara yang sah (AlSabouni, 2005). Perpindahan sebuah harta kepada seseorang di lakukan setelah terjadinya kematian. Dengan demikian harta tersebut beralih kepada ahli waris. Tanpa membedakan antara lakilaki dan perempuan. 
Kitab suci Al-Qur'an menjelaskan dengan sempurna dan lengkap tentang hukum kewarisan. Dengan demikian AlQur'an Al-Karim merupakan sandaran dalam hukum kewarisan dan nilai pembagiannya. Hanya sedikit hukum kewarisan yang ditetapkan berdasarkan haditshadits Rasulullah SAW dan Ijma' ulama. Selain hukum Islam, yang terdapat dalam Al-Qur'an tidak ada yang bisa menjelaskan secara detail tentang hukum kewarisan. Hal itu, tidak lain karena kewarisan merupakan salah satu bagaimana telah diketahui merupakan sendi kehidupan manusia, baik individu maupun masyarakat dan dengannya berputarnya roda kehidupan.

Prinsip-prinsip hukum kewarisan sebelum Islam, dengan sistem kekeluargaannya yang patrineal (Suparman, 2007). Ada tiga pokok prinsip dalam kewarisan yaitu:

1) Yang berhak mewarisi pertama adalah laki-laki dari pihak bapak yang terdekat atau disebut ashabah.

2) Perempuan serta anggota keluarga dari garis ibu, tidak mempunyai hak waris;
3) Selanjutnya anak, cucu, canggah, yang lebih berhak mewarisi dari pada leluhur pewaris, yaitu, ayah, kakak, maupun buyutnya.

Sebelum perkembangan Islam ketentuan hukum adat Arab yang telah berlaku sebelumnya. Kemudian setelah Hijrah ke Madinah berangsur-angsur diterapkan ketentuan-ketentuan baru (Thalib, 2004).

1. Hubungan darah.

Pada kasus ini siapa lakilaki yang bisa berperang dan punya ikatan hubungan darah, maka dapat mewarisi. Sebagai alasan dapat dilihat pada QS. AnNisa : 7 dan QS. An-Nisa : 11, 12, 33, 176.

2. Tidak diperlakukan bagi hubungan sebagai anak angkat untuk mewaris.

Al-Qur'an surat Al-Ahzab : 4 c yang berbunyi : "Tuhan tidak menjadikan anak angkat kamu itu menjadi anak kamu". Yang dimaksudkan di sini secara umum ialah Allah memberikan pernyataan bahwa anak angkat oleh seseorang sebagai anak angkat menurut hukum stradisi Arab ketika itu tindaklah berlaku lagi. Dahulu dalam hukum adat 
Arab, berlaku ketentuan bahwa anak angkat sama dengan anak salbi atau "anak kandung" yang mewarisi berdasarkan kedudukan sebagai anak angkat itu. Bagian dan kedudukannya sama dengan anak kandung. Seorang anak angkat menjadi "anak kandung" yang mewarisi berdasarkan kedudukannya sama dengan anak, dalam tingkat yang sama.

3. Hubungan janji untuk mewarisi.

Pada permulaan Islam, janji merupakan hal yang sangat penting. QS. An-Nisa : $33 \mathrm{c}$ dan d yang berbunyi: “......, bagi setiap orang Allah telah menjadikan mawali atas harta peninggalan orang yang mengadakan perjanjian dengan kamu, maka berikanlah bagian warisannya itu kepada mereka". Dari garis hukum ini ditarik ketentuan bahwa perjanjian menimbulkan hubungan saling mewarisi. Kemudian mewarisi berdasarkan atas perjanjian ini oleh sebagian sarjana Islam, tidak diperlakukan lagi. "Perjanjian" di sini diartikan mereka sebagai hubungan perkawinan.

4. Hijrah.
Orang yang sesama hijrah dalam permulaan pengembangan Islam itu saling mawaris sekalipun tidak mempunyai hubungan darah. Sedangkan dengan kaum kerabatnya yang tidak sesama hijrah bersama dia tidak saling mawaris. Hubungan mawaris karena hijrah ini kemudian dihapus dimansukhkan dengan QS. XXXIII : 6 dan QS. VIII : 75 yang berbunyi: "Orang yang sepertalian darah itu setengahnya lebih dekat kepada setengahnya".

5. Hubungan persaudaraan.

Rasul mempersaudarakan orang-orang tertentu sesamanya karena keperluan yang ada pada suatu waktu. Dan tindakan Rasul itu, mulanya menjadi sebab mereka yang dipersaudarakan itu saling mawaris. Kedudukan mawaris karena dipersaudarakan Rasul ini juga kemudian dihapus dimansukhkan dengan QS. XXXIII : 6 dan QS. VIII : 75 dan sebagainya.

\section{Kedudukan Wanita dalam Sistem Kewarisan Islam}

Kalau dahulu pada masa Quran turun menghadapi kenyataan yang hidup dalam masyarakat Arab, khususnya 
mengenai kedudukan wanita dalam sistem kewarisan yang sama sekali tidak memberikan hak meperoleh bagian warisan kepada wanita (AS, 1984). Maka akan berbeda sekali dengan apa yang kita hadapi dalam masyarakat kita (Indonesia) dewasa ini baik menganai keadaan kemajuan wanita maupun kedudukannya dalam sistem kewarisan.

Sebagaimana dalam hal menjadi saksi, dimana seorang perempuan hanya dihargai separo laki-laki dengan segala penjelasan yang menyertai, hadits pun memandang perempuan lebih rendah dibandingkan laki-laki dalam hal hak mewaris. Kedudukan perempuan dipandang hanya separoh dibandingkan dengan laki-laki (Muhibbin, 2007).

Kemudian dalam kaitannya dengan kemajuan wanita, sejarah telah membuktikan bahwa sejak zaman penjajahan Belanda di Indonesia telah terdapat pergerakan-pergerakan wanita dengan berbagai perkumpulan wanita serta dengan kegiatankegiatan konggres. Dalam pada itu kalau kita memperhatikan hasil-hasil dari konggreskonggres baik yang diselenggarakan oleh organisasi Perikatan Perempuan Indonesia (PPI) maupun yang diselenggarakan oleh Istri Indonesia (II), ternyata di samping memperhatikan masalah perubahan wanita, juga termasuk pula masalah perkawinan dan cerai, bahkan mengadakan penyelidikan mengenai kedudukan wanita menurut hukum Islam.

Kalau anak hanya perempuan saja, maka bagiannya adalah dzul faraidh, baik sendiri atau lebih dari seorang asalkan semuanya perempuan (Thalib, 2004). Allah khusus menjamin perolehan anak perempuan karena di masa yang lalu mereka sama sekali tidak mewaris. Sebab itu ketegasan perolehan anak perempuan dalam Al-quran sangat tetap dan sangat membantu penetapan hukum kewarisan Islam. Kalau tidak ada jaminan sedemikian, rasanya kita akan tenggelam lagi dalam persoalan dan debat persoalan anak perempuan itu.

Kedudukan anak perempuan sebagai ahli waris menurut 
hukum Islam pada dasarnya tergolong dzawul Faraidh yang bagian warisannya telah ditentukan dalam Al-Quran, dan anak perempuan bisa menjadi ashabah apabila mewaris bersama saudaranya yang laki-laki (anak laki-laki) (Manau, 2002).

Secara garis besar secara umum para ahli waris perempuan itu ada tujuh orang dan secara terperinci ada sepuluh orang. 1). Anak perempuan 2). Ibu, 3). Anak perempuannya anak lakilaki dan seterusnya ke bawah, 4). Ibunya ibu (nenek) dan seterusnya ke atas, 5). Ibunya bapak dan seterusnya ke atas, 6). Saudara perempuan sekandung, 7). Saudara perempuan seayah, 8). Saudara perempuan seibu, 9). Istri, 10). Perempuan yang memerdekakan budak/hamba sahaya (Labib dan Qisthi, 2005).

Kemudian mengenai beberapa hak yang semestinya diperoleh kaum perempuan, sebagaimana yang dapat diperoleh kaum laki-laki, sesungguhnya Alquran juga memberikan kesempatan yang sama. Perbedaan hanya terletak pada usaha masing-masing. Firman Allah dalam surat Al-
Nahl ayat: 97 mengisyaratkan hal ini, yakni :

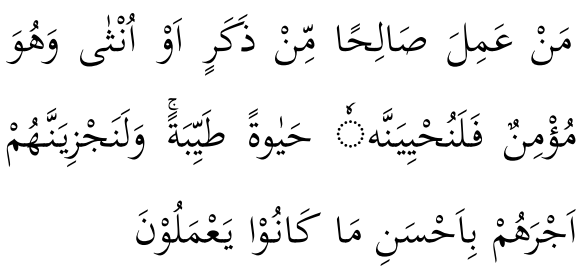

"Barang siapa yang mengajarkan amal saleh, baik laki-laki maupun perempuan dalam keadaan beriman, maka sesungguhnya akan kami berikan kepadanya kehidupan yang baik. Dan sesungguhnya akan kami beri balasan kepada mereka dengan pahala yang lebih baik dari pada apa telah mereka kerjakan." (QS. Al-Nahl [16]: 97)

Demikian juga firman Allah dalam surat Al-Nisa ayat: 32, lebih mempertajam penegasan tersebut, yakni:
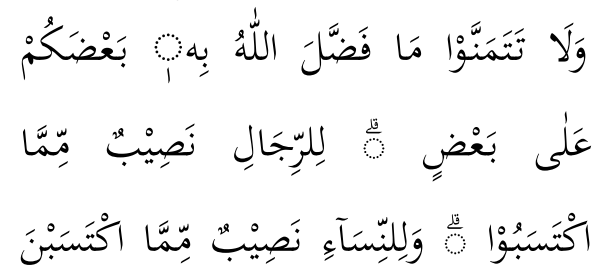

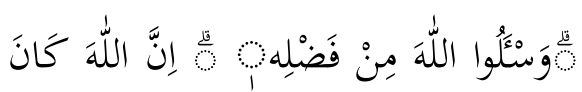
بِكُلِّ شَيِِْ عَلِيْمًا "Dan janganlah kamu iri hati terhadap apa yang dikaruniakan oleh Allah kepada sebagian kamu lebih banyak dari sebagaian yang 
lain. (karena) bagi orang lakilaki ada bagian dari pada apa yang mereka usahakan, dan mohonlah kepada Allah sebagian dari karunia-Nya. Sesungguhnya Allah Maha Mengetahui segala sesuatu." (QS. An-Nisa [4]: 32)

\section{Menurut KUH Perdata} (BW) anak-anak mendapat bagian yang sama banyaknya baik lakilaki maupun perempuan, sedangkan menurut hukum Islam bagian anak laki-laki dua kali bagian anak perempuan tetapi bila situasi kondisi memerlukan lain dari dibatasi dengan mempergunakan lembaga wasiat berdasarkan Surah Al-Baqarah: 180 atau lembaga fakir miskin dan anak yatim berdasarkan Surah An-Nisa: 8, atau berdasarkan musyawarah dan mufaakat (Ramulyo, 2004).

Hasil induksi atas seluruh kondisi dimana wanita memperoleh warisan menunjukkan bahwa hanya dalam kondisi wanita memperoleh harta warisan 1:2 bagian yang diperoleh kaum pria. Diluar kondisi keempat kondisi tersebut, wanita memperoleh bagian yang sejajar, bahkan lebih, atau malah sendirian dalam menikmati hasil warisan tanpa meyisakannya untuk pria (Sulthan, 2006).

\section{E. Analisis Sosiologi Hukum terhadap Kedudukan Wanita dalam Kewarisan Islam}

Pada

pembahasan sebelumnya ini telah diuraikan hal-hal yang berkenaan dengan perbedaan pendapat di kalangan ulama dalam menghadapi sesuatu pemecahan masalah, baik disebabkan oleh berbedanya paham mereka dalam penggunaan dalil syara' atau berbeda dalam memahami dalil syara' itu. Begitu pula pendapat yang berkembang dalam menghadapi pemecahan masalah yang disebabkan oleh munculnya masalah baru yang tidak terdapat pemecahannya dalam Alquran atau Sunnah Nabi, atau mungkin ada petunjuknya tetapi beberapa kesulitan timbul waktu memahami petunjuk yang ada petunjuk yang ada tersebut. Disini akan dicoba melihat permasahalan itu satu per satu memperkirakan sebab-sebab terjadinya masalah.

Dalam surah An-Nisa ayat 11 dijelaskan bahwa "bila anak perempuan lebih dari dua orang, mereka mendapat 2/3" 
(Syaifuddin, 2004). Maka seorang anak perempuan dan seorang saudara perempuan yang belum berkeluarga memperoleh $1 / 2$. Kalau mereka itu lebih dari seorang, mereka memperoleh $2 / 3$. Kalau seorang saudara laki-laki bergabung dengan mereka, maka laki-laki memperoleh dua bagian perempuan di dalam kedua kelompok itu, yakni mereka tidak mewarisi sebagai ashhabul furudh, melainkan sebagai kerabat (Subhani, 2002). Telah bersabda Rasulullah SAW, kepada Sa'ad bin Rabi' yang mempunyai saudara laki-laki: "Berikanlah dua pertiga (dari pusaka) kepada dua anak perempuan Sa'ad dan kepada ibu mereka seperdelapan, dan selebihnya buatmu".

Hadits tersebut dapatlah dipastikan bahwa telah turun secara serentak Surah An-Nisa ayat $11-12$.

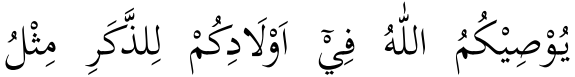

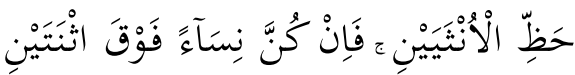

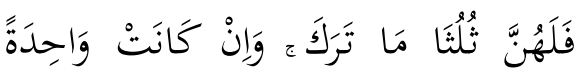

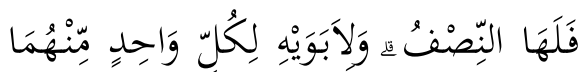

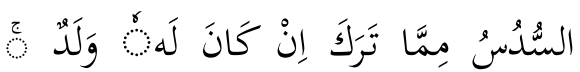

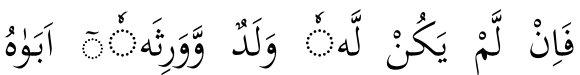

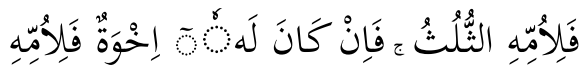

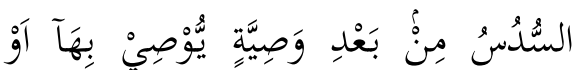

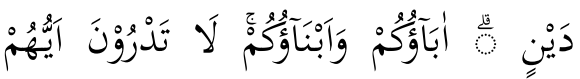

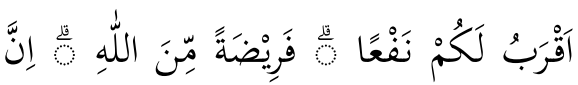

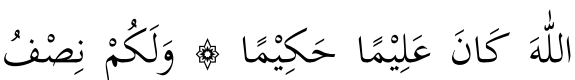

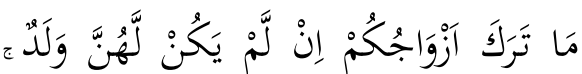

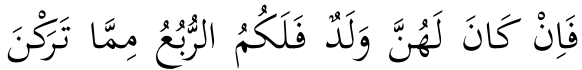

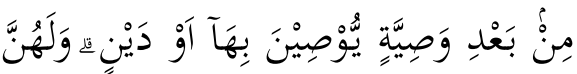

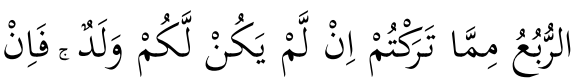

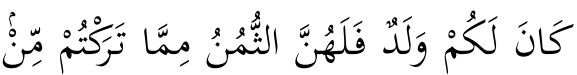

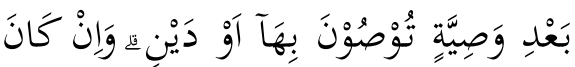

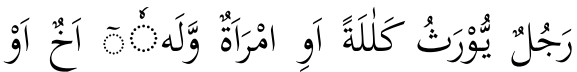

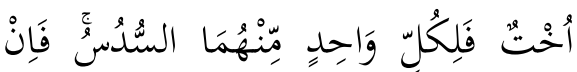

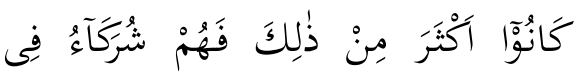

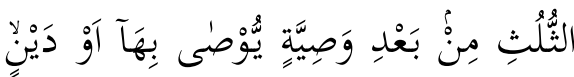

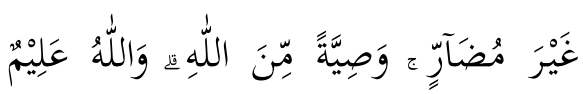
حَلِّoْ 
"Allah mensyari'atkan bagimu tentang (pembagian pusaka untuk) anak-anakmu. Yaitu : bahagian seorang anak lelaki sama dengan bagahian dua orang anak perempuan; dan jika anak itu semuanya perempuan lebih dari dua, Maka bagi mereka dua pertiga dari harta yang ditinggalkan; jika anak perempuan itu seorang saja, Maka ia memperoleh separo harta. dan untuk dua orang ibubapa, bagi masing-masingnya seperenam dari harta yang ditinggalkan, jika yang meninggal itu mempunyai anak; jika orang yang meninggal tidak mempunyai anak dan ia diwarisi oleh ibu-bapanya (saja), Maka ibunya mendapat sepertiga; jika yang meninggal itu mempunyai beberapa saudara, Maka ibunya mendapat seperenam. (Pembagian-pembagian tersebut di atas) sesudah dipenuhi wasiat yang ia buat atau (dan) sesudah dibayar hutangnya. (Tentang) orang tuamu dan anak-anakmu, kamu tidak mengetahui siapa di antara mereka yang lebih dekat (banyak) manfaatnya bagimu. ini adalah ketetapan dari Allah. Sesungguhnya Allah Maha mengetahui lagi Maha Bijaksana." (QS. An-Nisa : 11) "Dan bagimu (suami-suami) seperdua dari harta yang ditinggalkan oleh isteri-isterimu, jika mereka tidak mempunyai anak. jika isteri-isterimu itu mempunyai anak, Maka kamu mendapat seperempat dari harta yang ditinggalkannya sesudah dipenuhi wasiat yang mereka buat atau (dan) seduah dibayar hutangnya. Para isteri memperoleh seperempat harta yang kamu tinggalkan jika kamu tidak mempunyai anak. jika kamu mempunyai anak, Maka Para isteri memperoleh seperdelapan dari harta yang kamu tinggalkan sesudah dipenuhi wasiat yang kamu buat atau (dan) sesudah dibayar hutang-hutangmu. jika seseorang meninggal, baik lakilaki maupun perempuan yang tidak meninggalkan ayah dan tidak meninggalkan anak, tetapi mempunyai seorang saudara lakilaki (seibu saja) atau seorang saudara perempuan (seibu saja), Maka bagi masing-masing dari kedua jenis saudara itu seperenam harta. tetapi jika saudara-saudara seibu itu lebih dari seorang, Maka mereka 
bersekutu dalam yang sepertiga itu, sesudah dipenuhi wasiat yang dibuat olehnya atau sesudah dibayar hutangnya dengan tidak memberi mudharat (kepada ahli waris). (Allah menetapkan yang demikian itu sebagai) syari'at yang benar-benar dari Allah, dan Allah Maha mengetahui lagi Maha Penyantun." (QS. AnNisa [14]: 12)

Sajuti Thalib, merinci Surah An-Nisa ayat 11 ini dalam garis hukum kewarisan sebagai berikut (Ramulyo, 2004):

a. Allah menentukan mengenai harta warisan untuk anakanakmu, adalah untuk seorang anak laki-laki sebanyak bagian dua orang anak perempuan.

b. Jika anak-anakmu itu hanya perempuan saja dan jumlahnya ada dua orang atau lebih mereka mendapat dua pertiga $(2 / 3)$ bagian harta peninggalan.

c. Jika anak perempuan itu hanya seorang saja maka bagiannya seperdua (1/2) harta peninggalan.

d. Bagi dua orang ibu-bapak, masing-masingnya mendapat seperenan (1/6) dari harta peninggalan kalau pewaris meninggalkan anak. e. Jika pewaris tidak meninggalkan anak dan mewarisi ibu-bapaknya, bagi ibu sepertiga (1/3) yaitu jika tidak ada baginya saudara.

f. Jika pewaris tidak meninggalkan anak tetapi ada baginya saudara dan mewarisi ibu-bapaknya maka bagi ibunya mendapat seperenam (1/6).

g. Pelaksanaan pembagian harta warisan termaksud dalam garis hukum (a) sampai (f) itu, sesudah dibayarkan wasiat atau utang pewaris.

h. Ibu-bapak kamu dan anakanak kamu tidak kamu tahu mana di antara mereka yang lebih dekap kemamfaatannya kepada kamu.

Bagian anak perempuan adalah $1 / 2$ bagian jika seorang, $2 / 3$ bagian jika beberapa orang, masing-masing 1 bagian dari sisa jika mereka mewaris bersama anak laki-laki. Dalam hal ini kedudukan anak perempuan adalah sebagai ashabah bil-ghair (Salman dan Haffas, 2002).

Dasar hukumnya adalah sebagai berikut:

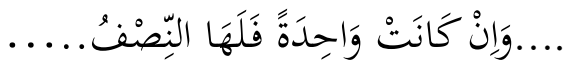


Jika anak perempuan itu seorang saja, maka ia memperoleh separo harta(Q.S. An-Nisa [4]: 11)

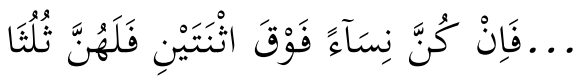
مَا تَرَكَكَ...

Dan jika anak itu semuanya perempuan lebih dari dua, maka bagian mereka dua pertiga dari harta yang ditinggalkan...(Q.S. An-Nisa: 11)

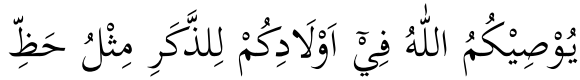

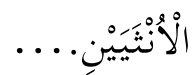

Bagian seorang anak lelaki sama dengan bagian dua orang anak perempuan...(Q.S. An-Nisa [4]: 11)

Permasalahan di sini muncul karena adanya kata "fawqa" dalam ayat ini yang berarti "lebih dari". Sebenarnya kata itu sendiri tidak samar dan dapat dipahami dengan mudah hanya dengan melihat susunan kalimat tersebut. Namun, kemudahan pemahaman ini agak terganggu oleh dua hal. Pertama : dalam ayat 176 surah An-Nisa yang membicarakan hak saudara perempuan disebutkan: "Bila saudara perempuan itu ada dua orang mereka mendapat $2 / 3$ ”.
Hak furudh yang 2/3 itu dinyatakan untuk 2 orang, bukan untuk "lebih dari" dua orang. Hak yang akan didapat oleh anak perempuan dan saudara perempuan ini adalah sama sedangkan pada saudara tidak terdapat kata "lebih dari" sebagaimana yang terdapat pada anak perempuan. Dengan memperbandingkan kedua kasus ini sepertinya timbul anggapan samanya dua keadaan ini. Kedua: adanya sepotong hadits Nabi dalam kasus janda Saad yang membawa dua anak perempuannya kepada Nabi yang kemuadian menetapkan "dua" anak perempuan itu menerima $2 / 3$.

Dalam kasus ini Ibnu Abbas berpendapat bahwa apabila ada 2 orang anak perempuan saja, maka mereka mendapat $1 / 2$ dan tidak berhak atas $2 / 3$. Alasannya ialah bahwa ayat ini secara jelas menetapkan bahwa yang mendapat $2 / 3$ itu adalah bila anak perempuan itu lebih dari 2 orang dan tidak kalau anak perempuan "hanya" 2 orang (Syaifuddin, 2004).

Untuk dua orang saudara perempuan secara detail Allah 
menyebutkan dalam surah AnNisa ayat 176 menyatakan bahwa bagiannya adalah 2/3. Oleh karena yang dimaksud hak $2 / 3$ untuk anak perempuan itu adalah jika mereka berdua sebagaimana berlaku terhadap saudara perempuan, karena dalam hal ini kedudukan mereka adalah sama.

\section{IV.KESIMPULAN}

Kedudukan dan hak wanita sebagai penerus ahli waris dalam hukum kewarisan merupakan suatu kewajiban setiap ahli waris. Berdasarkan nash Al-Qur'an, dimana disebutkan bahwa hak seorang wanita adalah 2:1. Kedudukan wanita dalam kewarisan Islam sama bagiannya dengan kedudukan laki-laki hanyalah perbedaan pembagian tersebut bukan karena persoalan gender. Namun melainkan atas tugas dan tanggung jawab seorang laki-laki lebih besar dibandingkan dengan yang dibebankan kepada perempuan.

Hak seorang wanita dalam kewarisan, memang menjadi problem dalam suatu keluarga. Dimana disatu sisi menggunakan pembagian secara kekeluargaan, namun disisi lain menggunakan hukum syar'i. Ini dapat kita lihat dalam kehidupan masyarakat yang kurang akan pengetahuan tentng hukum kewarisa. Dapat disimpulkan bahwa pembagian seorang wanita tetap pada porsi $2: 1$. Namun, pembagian tersebut dapat dilakukan dengan berbagai macam cara. Selama pembagian tersebut dapat memberikan rasa keadilan serta keseimbangan.

Dalam

berbagai

kesempatan, penulis menyampaikan kepada pembaca bahwa pengetahuan kewarisan penting dikuasai. Tujuannya untuk diimplementasikan sesuai dengan kebutuhan masyarakat.

Ketika ada masalah dalam hal kewarisan maka cobalah untuk dimusyawarakan secara kekeluargaan. Karena dengan begitu semua persoalan yang terjadi tidak begitu sulit yang kita hadapi.

\section{DAFTAR PUSTAKA}

Al-Sabouni, M.A. (2005). Hukum Kewarisan Menurut Al-Qur'an dan Sunnah. Jakarta: Dar Al-Kutub Al-Islamiyah. 
Ash Shiddieqy, T.M.H. (2001). Fiqh Mawaris. Semarang: Pustaka Rizki Putra. . (2010). Fiqh Mawaris. Semarang: Pustaka Rizki Putra.

Anshary, (2017). Hukum Kewarisan Islam dalam teori dan Praktik. Yogyakarta: Pustaka Pelajar.

Burhan, M. (2017). Kedudukan dan hak perempuan sebagai ahli waris dalam hukum kewarisan Indonesia (tinjauan hukum perdata, adat dan Islam). Palembang: Mahkamah.

Departemen Agama RI, (2007). Al-Qur'an dan Terjemah. Bandung: PT. Remaja Rosdakarya.

Djakfar, I. \& Taufik Y. (1995). Kompilasi Hukum Kewarisan Islam. Jakarta: PT. Dunia Pustaka Jaya.

Haffas, O.S.M. (2002). Hukum Waris Islam. Bandung: PT. Refika Aditama.

Hajar, M. (2008). Hukum Kewarisan Islam Fiqih Mawaris. Pekanbaru: Alaf Riau.

Hasbiyallah, (2007). Belajar Ilmu Waris. Bandung: PT. Remaja Rosdakarya.

Kasim, N.M. (2014). Hukum Islam dan Masalah Kontemporer. Yogyakarta: Interpena.

Khan, A.M.S. (2001). Al-Qu'an dan As-Sunnah Bicara Wanita. Jakarta: Darul Falah.

Manau, A. (2002). Status Hukum anak Perempuan menurut Hukum kewarisan (Adat, Islam, EX. Barat). Fakultas Agama Islam Universitas Alkhairaat Palu.

Masud, I. \& Zainal A. (2000). Fiqhi Madzhab Syafi'i. Bandung: CV. Pustaka Setia.

Muhibbin. (2007). Pandangan Islam terhadap Perempuan. Semarang: Rasail Media.

Labib, Mz dan Aqil B.Q. (2005) Risalah Fiqih Wanita. Surabaya.

Parman, A. (1995). Kewarisan dalam Alquran Suatu Kajian Hukum dengan Pendekatan Tafsir Tematik. Jakarta: Raja Grafindo Persada. 
Ramulyo, I. (2004). Perbandingan Hukum Kewarisan Islam dengan Kewarisan Kitab Undang-undang Hukum Perdata. Jakarta: Sinar Grafika.

Rofiq, A. (1998). Fiqh Mawaris. Jakarta: PT. Raja Grafindo Persada. . (2003). Hukum Islam di Indonesia. Jakarta: PT. Raja Grafindo Persada.

Subhani, J. (2002). Yang Hangat dan Kontroversial dalam Fiqih. Jakarta: PT. Lentera Basritama.

Suganda, A. (2020). Konsep Kalalah dalam Fiqih Waris. Sukabumi: AtTatbiq: Jurnal Ahwal al-Syakhsiyyah (JAS).

Sulthan, S. (2006). Wanita lebih Unggul dari Pria dalam Kewarisan dan Nafkah. Jakarta: Pustaka Azzam.

Suparman, E. (2007). Hukum Waris Indonesia dalam Prespektif Islam, Adat, dan BW. Bandung: PT. Refika Aditama.

Syarifuddin, A. (2003). Garis-garis Besar Fiqh. Jakarta: Kencana. . (2004). Hukum Kewarisan Islam. Jakarta: Prenada Media.

Thalib, S. (2004). Hukum Kewarisan Islam di Indonesia. Jakarta: Sinar Grafika. 